\title{
Gastrointestinal endoscopic practice during COVID-19 pandemic: a multi-institutional survey
}

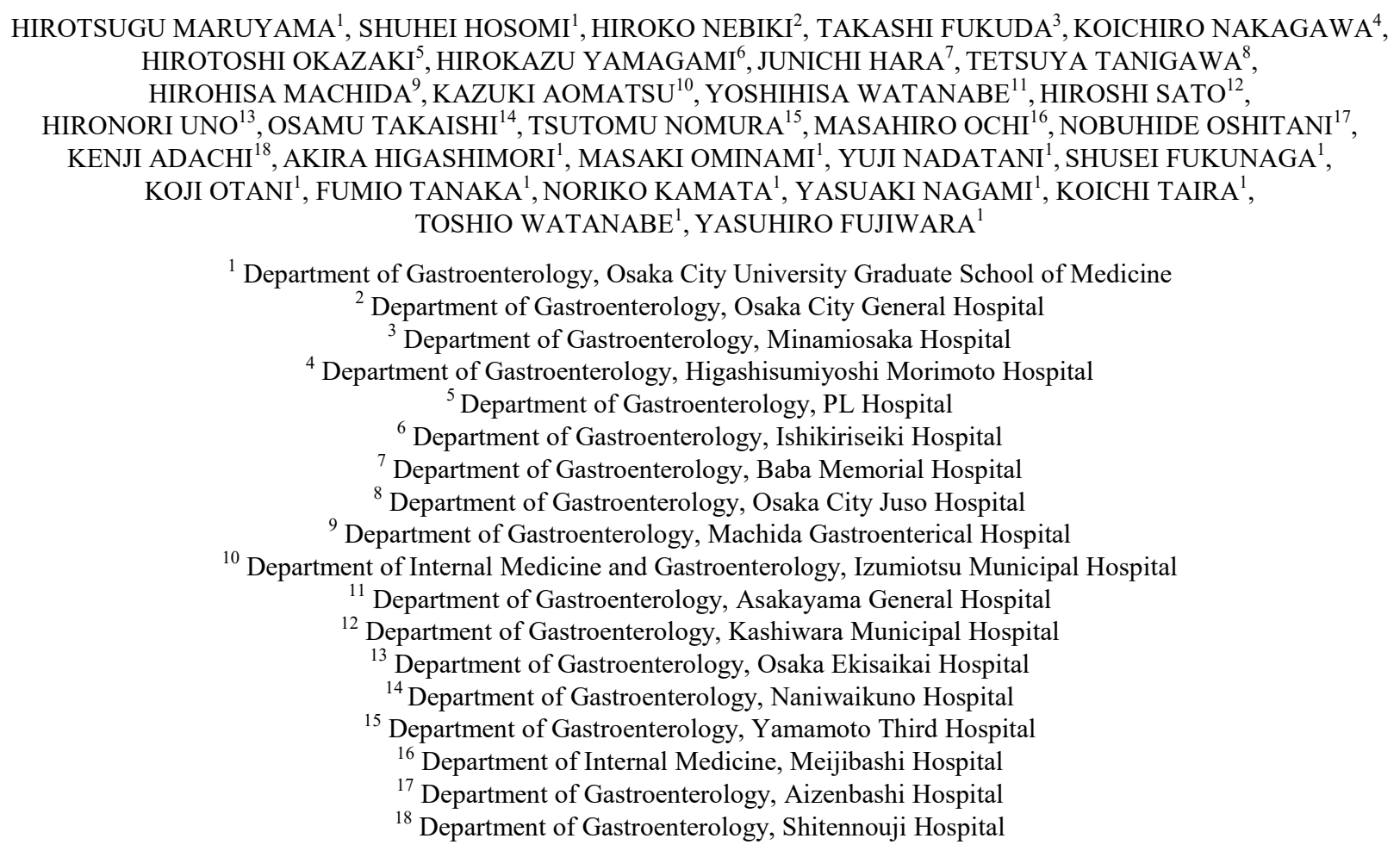

Introduction. An on-going coronavirus disease 2019 (COVID-19) has become a challenge all over the world. Since an endoscopy unit and its staff are at potentially high risk for severe acute respiratory syndrome coronavirus 2 (SARS-CoV-2) infection, we conducted a survey for the management of the gastrointestinal endoscopic practice, personal protective equipment (PPE), and risk assessment for COVID-19 during the pandemic at multiple facilities.

Methods. The 11-item survey questionnaire was sent to representative respondent of Department of Gastroenterology, Osaka City University Hospital, and its 19 related facilities.

Results. A total of 18 facilities submitted valid responses and a total of 373 health care professionals (HCPs) participated. All facilities (18/18: 100\%) were screening patients at risk for SARS-CoV-2 infection before endoscopy. During the pandemic, we found that the total volume of endoscopic procedures decreased by 44\%. Eleven facilities (11/18: 61\%) followed recommendations of the Japan Gastroenterological Endoscopy Society (JGES); consequently, about $35 \%-50 \%$ of esophagogastroduodenoscopy and colonoscopy were canceled. Mask (surgical mask or N95 mask), face shield/goggle, gloves (one or two sets), and gown (with long or short sleeves) were being used by endoscopists, nurses, endoscopy technicians, and endoscope cleaning staff in all the facilities (18/18: 100\%). SARS-CoV-2 infection risk assessment of HCPs was conducted daily in all the facilities (18/18: 100\%), resulting in no subsequent SARS-CoV-2 infection in HCPs.

Conclusion. COVID-19 has had a dramatic impact on the gastrointestinal endoscopic practice. The recommendations of the JGES were appropriate as preventive measures for the SARSCoV-2 infection in the endoscopy unit and its staff.

Key words: COVID-19, endoscopy, SARS-CoV-2, survey, personal protective equipment.

\section{What is new? What is important?}

The present report is important for resuming full endoscopy services during the pandemic. 


\section{INTRODUCTION}

An on-going coronavirus disease 2019 (COVID-19) outbreak has been declared a pandemic by the World Health Organization [1] and managing this disease has become quite challenging worldwide. A mild lockdown was declared in Japan from April to May 2020. Since an endoscopy unit and its staff are at potentially high risk for contracting severe acute respiratory syndrome coronavirus 2 (SARSCoV-2) infection, and hence virus transmission, gastrointestinal endoscopic practices have changed drastically. This could lead to the collapse of many healthcare systems in the world. However, evidencebased guidelines for endoscopy practice and clinical information pertaining to the COVID-19 pandemic are still lacking [2].

Health care professionals (HCPs) in endoscopy units could be at higher risk for SARS-CoV-2 infection owing to the inhalation of aerosols and airborne droplets, conjunctival contact, and potential fecal-oral transmission from the infected individuals [3-5]. Therefore, similar to the gastrointestinal endoscopy society of different countries (e.g. American Society for Gastrointestinal Endoscopy (ASGE) and European Society of Gastrointestinal Endoscopy), the Japan Gastroenterological Endoscopy Society (JGES) (https://www.jges.net/medical/ covid-19-proposal) has also joined forces for providing recommendations to assure the highest level of protection against COVID-19 for both patients and HCPs. In response, facilities providing endoscopy services have taken immediate action to protect patients and staff; however, the extent of implementation of these recommendations among the facilities is unknown. Meanwhile, according to an Italian report [6], the infection rate of HCPs engaged in endoscopy units was low even during the pandemic, and no cluster occurrence in endoscopy units has been reported until now in Japan.

The risk of SARS-CoV-2 infection in gastrointestinal endoscopic practices is also unknown. To resume full endoscopy services, we need to obtain information on gastrointestinal endoscopic practices during the pandemic.

Osaka is the region with the second most SARS-CoV-2 infected cases in Japan. We, therefore, conducted a survey on the management of gastrointestinal endoscopic practices, personal protective equipment (PPE), and risk assessment for COVID-19 during the pandemic at multifacilities.

\section{MATERIALS AND METHODS}

\section{Participating facilities}

This was a retrospective study conducted at multi-facilities. The Department of Gastroenterology at Osaka City University Hospital and its 19-related facilities participated in the survey. Each related institution is a recommended institution by the JGES, and the quality of the endoscopy unit and infection protection measures was guaranteed.

\section{Survey questionnaire}

Core members of the research team (H.M and S.H) drafted and revised a structured 11-item questionnaire. This questionnaire was based on a comprehensive review of the literature and recommendations of the JGES, and was emailed to the representative of each facility. The questionnaire consisted of multiple questions in the following categories: (1) management of gastrointestinal endoscopic practice, (2) risk assessment for COVID-19, and (3) protective measures for patients and HCPs in the endoscopy unit. The surveys were completed within 28 days from May 13 to June 9, 2020. We contacted the representative of each institution again if there was no response after 14 days.

\section{Data collection period}

We acquired the data from March to April 2020. The data during the pandemic period were those of April 2020. As a control, we also acquired data from March to April 2019.

\section{Ethical consideration}

The ethics committee of the Osaka City University Graduate School of Medicine approved the study's protocol (number 2020-146).

\section{Statistical analysis}

Categorical variables were expressed as frequencies and percentages. Graphic presentations were derived from the obtained data.

\section{RESULTS \\ Overview}

A total of 18 facilities responded to the survey, while 2 facilities did not respond (Figure 1). A total 
of 373 HCPs participated: 164 endoscopists (all medical doctors, 44\%), 140 nurses (37\%), 30 endoscopy technicians $(8 \%)$, and 39 endoscope cleaning staff
(11\%) were involved during the survey period. Most endoscopists spent 5 to 6 days a week in endoscopy units before and during the pandemic.

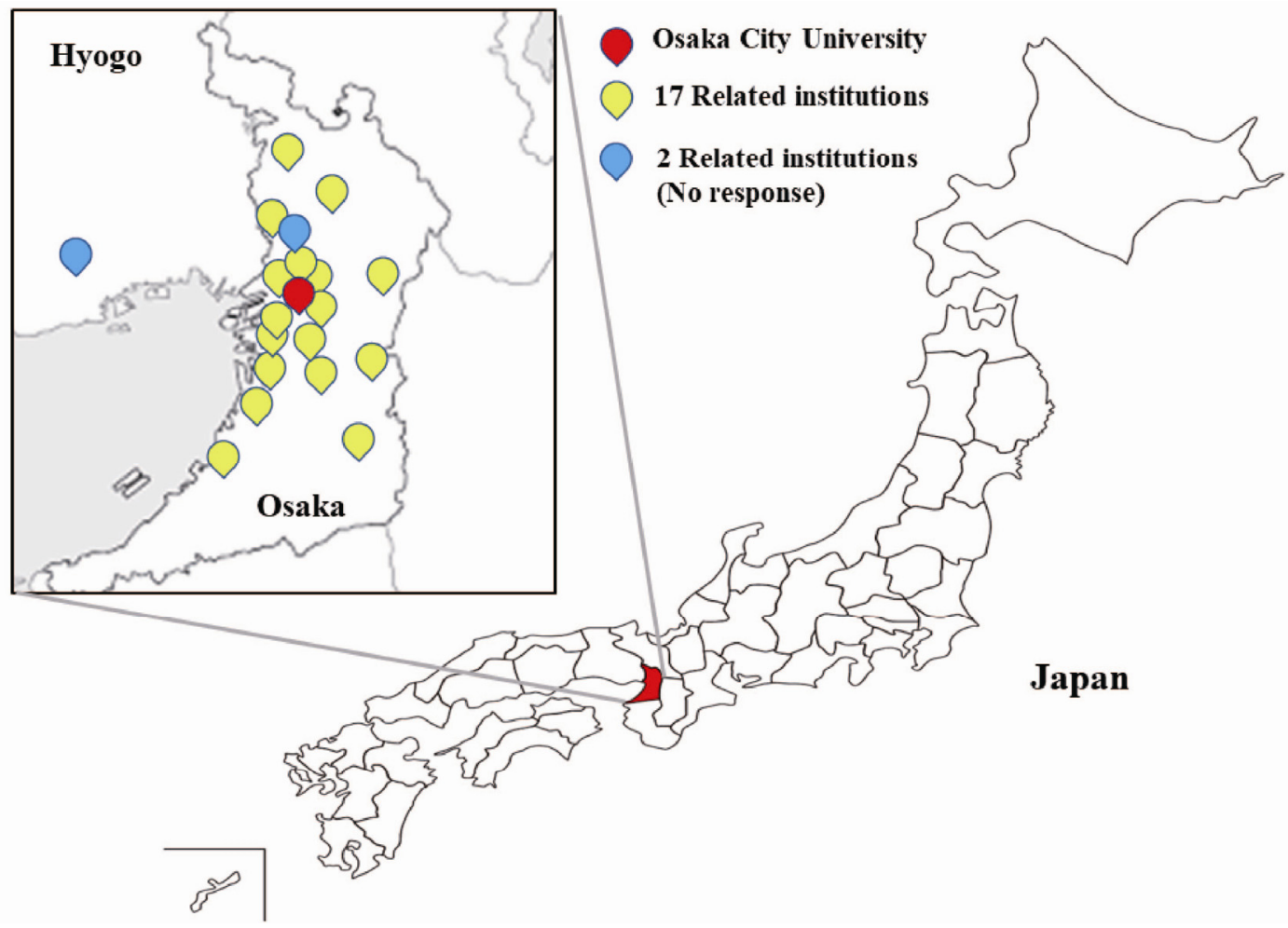

Figure 1. Geographic locations of the facilities that responded to the survey.

\section{Management of gastrointestinal endoscopic practice during the pandemic}

All facilities (18/18: 100\%) prescreened patients at risk for SARS-CoV-2 infection upon arrival to the endoscopy units based on symptoms and/or exposure assessments, and target patients had their endoscopies canceled. According to the Japanese Association for Infectious Diseases, the indication of polymerase chain reaction (PCR) test for SARS-CoV-2 during the pandemic in Japan was "a pneumonia patient who needed hospitalization and treatment, and a case with strongly suspected viral pneumonia". Therefore, PCR testing was not performed on all patients with cancelled endoscopies, since some cases did not meet the criteria. We took care not to perform local anesthesia using a lidocaine spray. The reasons for COVID-19 screening before endoscopy were as follows: 1) fever $>37.5^{\circ} \mathrm{C}$ (17/18: 94\%); 2) close contact history with patients infected with SARS-CoV-2 within 2 weeks (16/18: $89 \%$ ); 3) travel history to high-risk countries within 2 weeks during pandemic (16/18: 89\%); 4) fatigue and respiratory symptoms (16/18: 89\%); 5) abnormal taste and smell sensations (11/18:
$61 \%)$; 6) gastrointestinal symptoms lasting 4-5 days (3/18: 17\%); and, 7) body temperature measurement (16/18: 89\%).

The recommendations of the JGES for the gastrointestinal endoscopic practice during the pandemic were divided into 7 categories [7]. Their description and implementation rate in each institution are as follows: 1) gastrointestinal bleeding or suspected gastrointestinal bleeding (18/18: 100\%); 2) cholangitis or obstructive jaundice that requires treatment using an endoscope (15/18: 83\%); 3) symptomatic biliarypancreatic disease that requires treatment using an endoscope other than 2) (13/18: 73\%); 4) gastrointestinal stricture that may affect oral intake (13/18: 73\%); 5) gastrointestinal cancers that require treatment using an endoscope (15/18: 83\%); 6) other urgent endoscopy procedures that have been decided by the head of the facility (17/18: 94\%); 7) screening or surveillance of asymptomatic individuals (7/18: $39 \%$ ) (Table 1). Four facilities (4/18: 22\%) restricted endoscopies by trainees. Two facilities (2/18: 11\%) owned negative pressure endoscopy rooms, however they were not used during this pandemic. There was no endoscopy practice for COVID-19 positive patients during the pandemic. 
Table 1

COVID-19 screening before endoscopy and implementation rate during the pandemic

1) Fever $\left(>37.5^{\circ} \mathrm{C}\right)$

\section{Screening}

$$
\%(\text { (n) }
$$

$94 \%(17 / 18)$

$89 \%(16 / 18)$

$89 \%(16 / 18)$

$89 \%(16 / 18)$

$61 \%(11 / 18)$

$17 \%(3 / 18)$

$89 \%(16 / 18)$

$\%(\mathrm{n})$

$100 \%(18 / 18)$

$83 \%(15 / 18)$

$73 \%(13 / 18)$

$73 \%(13 / 18)$

$83 \%(15 / 18)$

$94 \%(17 / 18)$

$39 \%(7 / 18)$

7) Screening or surveillance of asymptomatic individuals COVID-19: Coronavirus disease 2019.

\section{Changes in the volume of endoscopy}

During the period March to April 2019 (control period), the volume of gastrointestinal endoscopic procedure did not change at each facility. However, during the pandemic, half of the facilities $(9 / 18$ : $50 \%$ ) were operating at $<60 \%$ on their upper endoscopic procedures (esophagogastroduodenoscopy, endoscopic submucosal dissection (ESD), endoscopic mucosal resection (EMR), and endoscopic balloon dilation (EBD)) and lower endoscopic procedures (total colonoscopy, ESD, EMR, and EBD). The total volume of upper and lower endoscopic procedures at all the facilities in April 2020 decreased by $48 \%$ (from 4,498 to 2,361) and 36\% (from 2,429 to 1,562), respectively, compared to that in March 2020. However, the frequency of pancreatobiliary endoscopy (endoscopic retrograde cholangiopancreatography, endoscopic ultrasonography (EUS), and endoscopic ultrasound fine needle aspiration biopsy (EUSFNAB)) did not change much before and during the pandemic (Figure 2).

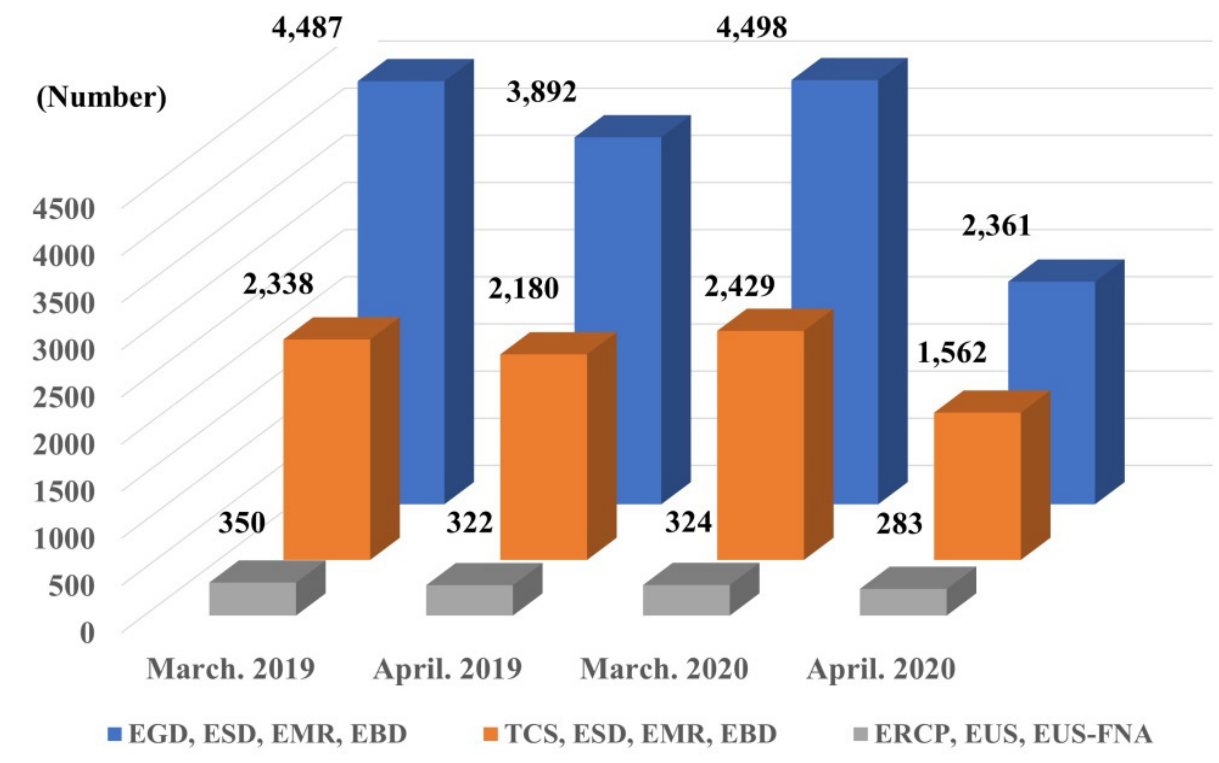

EGD: esophagogastroduodenoscopy, ESD: endoscopic submucosal dissection, EMR: endoscopic mucosal resection, EBD: endoscopic balloon dilatation, TCS: total colonoscopy, ERCP: endoscopic retrograde cholangiopancreatography, EUS: endoscopic ultrasonography, EUS-FNA: endoscopic ultrasound-guided fine needle aspiration

Figure 2. The volume of endoscopy procedures during the control (March 2019 to April 2019) and pandemic (March 2020 to April 2020) periods. 
The reduced volumes of endoscopy could be linked to: 1) recommendations of the JGES (17/18: 94\%); 2) lack of PPE (5/18: 28\%); 3) lack of HCPs owing to the COVID-19 medical treatment (1/18: $6 \%)$; 4) cancellations of the procedure by patients (16/18: 89\%); 5) presence of COVID-19 patients in the facility $(1 / 18: 6 \%)$; and, 6$)$ not decreasing (0/18: $0 \%)$ (Table 2).

\section{PPE processes and their utilization during the pandemic}

To mitigate the risk of infection, most endoscopic units issued new instructions for the risk-adapted PPE usage and informed their staff of the management of COVID-19 patients. Mask (surgical or N95 mask), face shield/goggle, gloves (1 or 2 sets), and gown (with long- or short-sleeves) were used by endoscopists, nurses, endoscopy technicians, and endoscope cleaning staff in all the facilities (18/18: 100\%). Although N95 masks were used by endoscopists and nurses in 2 facilities $(2 / 18$ : $11 \%)$ and cleaning staff in 1 facility (1/18: 6\%); they were not used by endoscopy technicians. A cap was used by endoscopists in 8 facilities (8/18: 44\%), nurses in 7 facilities (7/18: 39\%), endoscopy technicians in 4 facilities (4/18: $30 \%)$, and cleaning staff in 9 facilities (9/18: 50\%) (Figure 3).

Table 2

Reasons for the decreased endoscopy volume

\begin{tabular}{lc}
\hline \multicolumn{1}{c}{ Reason } & $\%(\mathbf{n})$ \\
\hline 1) According to the recommendations of JGES & $94 \%(17 / 18)$ \\
2) Lack of PPE & $28 \%(5 / 18)$ \\
3) Lack of HCPs due to COVID-19 medical treatment & $6 \%(1 / 18)$ \\
4) Cancellations of the practice by patients & $89 \%(16 / 18)$ \\
5) The occurrence of COVID-19 positive patients in the facility & $6 \%(1 / 18)$ \\
6) Not decreasing & $0 \%(0 / 18)$ \\
\hline
\end{tabular}

JGES: Japan Gastroenterological Endoscopy Society, COVID-19: Coronavirus disease 2019
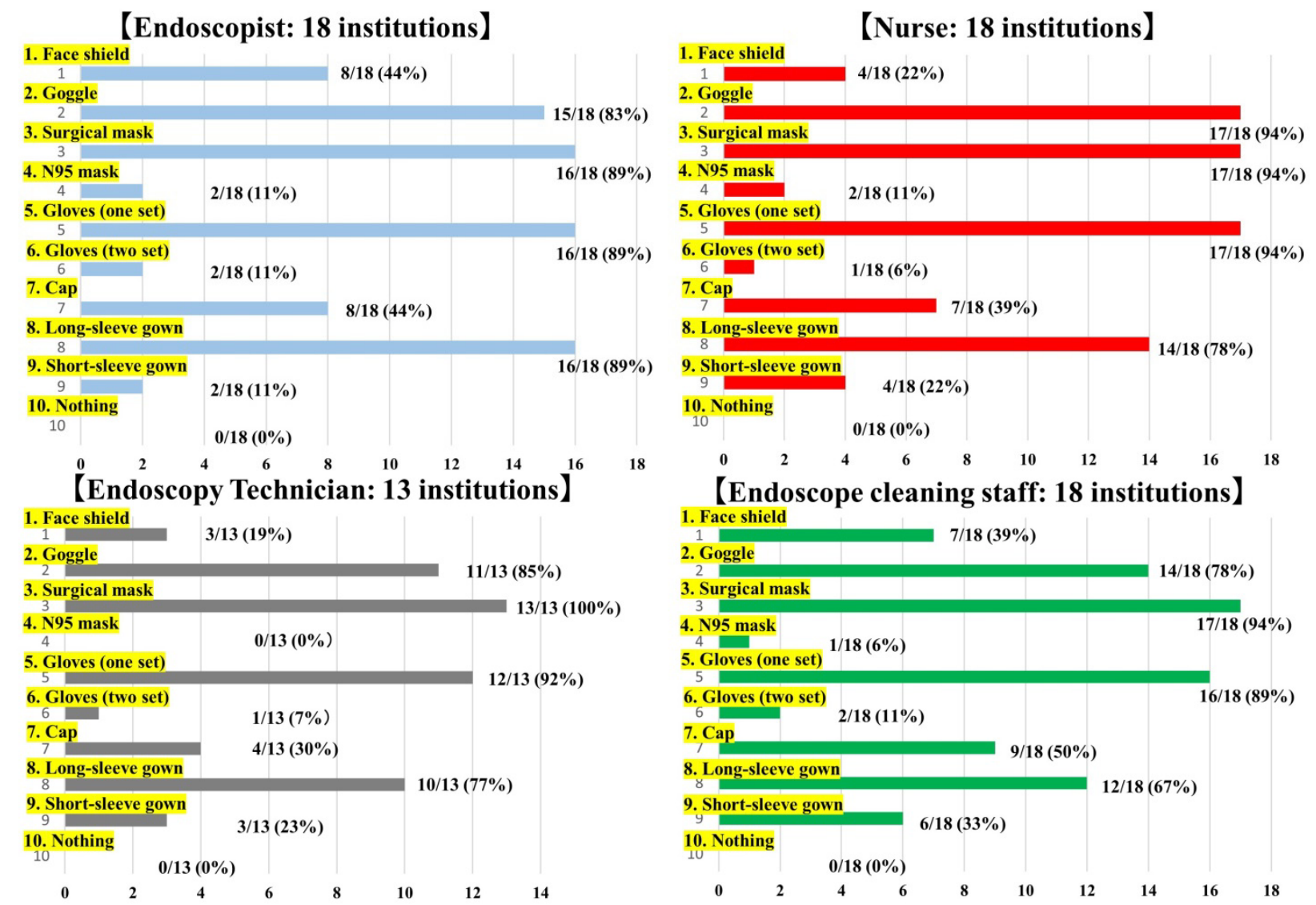

PPE: personal protective equipment

Figure 3. Characteristics of the PPE in endoscopy units that participated in the survey. 


\section{SARS-CoV-2 positives among HCPs during the pandemic}

SARS-CoV-2 infection risk assessment of HCPs was conducted daily in all facilities $(18 / 18$ : $100 \%$ ). Temperature measurements, travel history to high-risk countries during the pandemic, and respiratory, and gastrointestinal symptoms were checked in all facilities. No HCPs were infected with SARS-CoV-2 during the pandemic. A nurse (1/373: 0.27\%), who presented with fever and cough, was suspected of having COVID-19, but tested negative for SARS-CoV-2 on PCR.

\section{DISCUSSION}

We conducted a survey on the management of gastrointestinal endoscopic practice, PPE, and risk assessment for COVID-19 to evaluate the response during the COVID-19 pandemic at multiple facilities. During the pandemic, we found that the total volume of endoscopic procedures decreased by $44 \%$. Procedural measures were implemented as well, such as risk stratification of patients and adapted use of PPE other than the cap, resulting in no SARS-CoV-2 infection among HCPs. The present study comprised a the survey for obtaining real data on how endoscopy units coped during the first wave of COVID-19 pandemic and measures taken for ensuring a continued risk assessment for COVID-19. This information is important for resuming full endoscopy services during the pandemic.

During the pandemic, endoscopy societies recommended the postponing or cancellation of all but emergency and urgent endoscopic interventions [7, 8]. In our survey, 11 facilities (11/18: 61\%) followed the recommendations by the JGES; consequently, about $35 \%-50 \%$ of esophagogastroduodenoscopies and colonoscopies were canceled. In particular, screening or surveillance endoscopies for asymptomatic cases, such as pancreatic cysts, post-ESD with low risk of recurrence, and post polypectomy without large lesions were postponed, whereas scrutiny and treatment of gastrointestinal cancer were actively implemented. Interestingly, these endoscopies were affected strongly in high-volume facilities, whereas pancreatobiliary endoscopies were not affected in the present study. This finding was similar to a previous report [9]. As EUS and EUS-FNAB were implemented at only 4 facilities $(4 / 18: 22 \%)$ in this survey, the total volume of pancreatobiliary endoscopies was originally small. Therefore, the effect of the pandemic on pancreatobiliary endoscopy could not be fully evaluated.

As the PPE, standard precautions, even for the low-risk patients, are recommended by the JGES. It is recommended to use a face shield/goggle, gloves, a surgical mask, a cap, and a long-sleeve gown. In our results, the use of standard precautions other than surgical caps was suitable in all facilities. The use of the N95 mask and cap was limited to about $10 \%$ and $40 \%-60 \%$, respectively. This might be due to an inadequate supply during the first wave of COVID-19 in Japan. However, it is shown that N95 respirators and surgical masks have similar protective effects $[10,11]$. In addition, the use of a surgical cap in low-risk patients is not necessarily recommended by the ASGE and Asian Pacific Society for Digestive Endoscopy [12, 13]. Given these backgrounds, all the facilities involved in the present study were using the appropriate PPE for the low-risk patients, with no HCPs infected with SARS-CoV-2. Our results show that recommendations of the JGES provided appropriate protection.

The daily infection risk assessment of HCPs found a nurse suspected of having COVID-19. Although the PCR test for SARS-CoV-2 was negative in the present study, we believe that these procedural measures would be important for predicting infections and preventing cluster development.

To resume the elective endoscopic procedure, we need to improve several things. First is the prevention of new outbreaks: it is reported that the virus transmission can occur during the incubation period in asymptomatic patients, and even low-risk patients can be SARS-CoV-2 positive [14], suggesting that resuming endoscopic procedures would need careful preventive measures. Moreover, the appropriate PPE techniques and persistent risk assessments for both patients and HPCs should continue. Second is the number of daily endoscopic examinations. It will not be able to return immediately to the levels seen pre-pandemic. We would suggest reducing the number of daily endoscopic examinations and gradually increasing it to avoid crowding in the waiting room and recovery room. Third, selection and stratification of patients according to an order of priority will be necessary. In our survey, scrutiny and treatment of gastrointestinal cancer were actively implemented during the pandemic. Therefore, we would suggest gradually resuming screening or surveillance from clinically low risk patients. In particular, patients with previous history of dysplasia / cancer or clinical symptoms should be prioritized [15]. 
Restriction on training activities is recommended during the pandemic. Training activities will increase the risk of infection in all aspects. However, only a minority of the centers involved in the survey (4/18) restricted training activities. There is a difference between the previous and the present study. Although the major barrier for the exclusion of trainees was PPE shortage in the previous study [16], 72\% (13/18) of facilities in our survey had enough PPEs, which suggested that the situation was different from surveys in other countries. In addition, the number of SARS-CoV-2 positive patients in our survey was very small compared to that in the United States and Europe. During the pandemic, the JGES recommended restricting training activities in patients who had or were suspected of having COVID-19 [7]. However, there was no restriction for low risk patients if the standard precautions were not problematic. Therefore, we consider that only a minority of the facilities involved in our survey restricted training activities.

The present study has several limitations. First, this was a retrospective study. Secondly, we could not investigate the economic effect during the COVID-19 pandemic. Thirdly, there were no proven COVID-19 patients during this period. This might be due to the relatively low infection rate in Japan based on antibody testing $[17,18]$. However, the indications for PCR testing for SARS-CoV-2 were severely limited during the pandemic in Japan, both among patients and HCPs. It was impossible to accurately assess the real incidence of SARS-CoV-2 infection due to potentially asymptomatic carriers among patients and HCPs. The present study showed that the real-world data for the low-risk patient group and the risk for both patients and HCPs to acquire clinically relevant SARS-CoV-2 infection by means of endoscopy appear to be less, if we use the appropriate PPE.

\section{CONCLUSION}

In conclusion, COVID-19 has had a dramatic impact on the gastrointestinal endoscopy practice. The recommendations of the JGES for both the endoscopy unit and staff were appropriate as preventive measures for the SARS-CoV-2 infection. We believe that our data provide important information for resuming full endoscopy services during the pandemic.

Introducere. Pandemia COVID-19 este o provocare în îmtreaga lume. Întrucât endoscopia este o procedură cu risc pentu transmiterea infecției cu SARS-CoV-2 am realizat un sondaj asupra practicilor endoscopice, măsurilor de protecție (PPE) și managementul riscurilor în timpul pandemiei COVID-19.

Metode. A fost relizat un chestionar cu 11 itemi transmis la departamente de gastroenterology din Osaka, Japonia.

Rezultate. 18 centre au participat și 373 de angajați din sistemul medical au răspuns. Toate unitățile aplicau screening pentru infecția SARS-CoV-2 înaintea endoscopiei. Procedurile au scăzut în medie cu 44\% în timpul pandemiei. 11 unități respectau recomandările JGES. 50\% din colonoscopii au fost anulate. In toate unitățile erau folosite echipamente de protecție pentru întreg personalul. Analiza riscurilor asociate SARS-CoV-2 a fost realizată în toate unitățile și nu au fost raportate infecții în rândul personalului.

Concluzii. Pandemia COVID-19 are un impact dramatic asupra practicilor endoscopice. Recomandările JGES au fost eficiente ca măsuri de prevenție impotriva răspândirii bolii în cadrul unităților de endoscopie.

Correspondence to: Shuhei Hosomi, M.D, Ph.D, Department: Gastroenterology Institute/University/Hospital: Osaka City University Graduate School of Medicine: 1-4-3, Asahimachi, Abeno-ku, Osaka, 545-8585, Japan

Tel: $+81-6-6645-3811$

Fax: +81-6-6645-3813

E-mail:m1265271@med.osaka-cu.ac.jp

Acknowledgements: None.

Conflict of interest disclosure: The authors declare that there are no conflicts of interest. 


\section{REFERENCES}

1. WHO Director-General's opening remarks at the media briefing on COVID-19. https://www.who.int/dg/speeches/detail/whodirectorgeneral-s-opening-remarks-at-the-media-briefing-on-covid-19-11march-2020

2. GRALNEK IM, HASSAN C, BEILENHOFF U, ANTONELLI G, EBIGBO A, PELLISÈ M., et al. ESGE and ESGENA position statement on gastrointestinal endoscopy and the COVID-19 pandemic. Endoscopy. 2020; 52(6):483-90.

3. TANG JW, LI Y, EAMES I, CHAN PK, RIDGWAY GL. Factors involved in the aerosol transmission of infection and control of ventilation in healthcare premises. J Hosp Infect. 2006; 64(2):100-14.

4. HUANG C, WANG Y, LI X, REN L, ZHAO J, HU Y., et al. Clinical features of patients infected with 2019 novel coronavirus in Wuhan, China. Lancet. 2020; 395(10223):497-506.

5. GU J, HAN B, WANG J. COVID-19: Gastrointestinal manifestations and potential fecal-oral transmission. Gastroenterology $2020 ; 158(6): 1518-9$.

6. REPICI A, ARAGONA G, CENGIA G, CANTÙ P, SPADACCINI M, MASELLI R., et al. Low Risk of covid-19 Transmission in GI Endoscopy. Gut. 2020; 69(11):1925-7.

7. FURUTA T, IRISAWA A, MATSUMOTO T, KAWAI T, INABA T, KANNO A., et al. Clinical Questions and Answers on Gastrointestinal Endoscopy during the Novel COVID-19 Pandemic. Dig Endosc. 2020; 32(5):651-7.

8. BRITISH SOCIETY OF GASTROENTEROLOGY. Endoscopy activity and COVID-19: BSG and JAG recommendations update 03.04.20, https://www.bsg.org.uk/covid-19-advice/endoscopy-activity-and-covid-19bsg-and-jag-recommendations/, April 2020.

9. MAHADEV S, ARONIADIS OS, BARRAZA L, AGARUNOV E, GOODMAN AJ, BENIAS PC., et al. Impact of the COVID-19 pandemic on endoscopy practice: results of a cross-sectional survey from the New York metropolitan area. Gastrointest Endosc. 2020; 92(3):788-9.

10. SETO WH, TSANG D, YUNG RW, CHING TY, NG TK, HO M., et al. Effectiveness of precautions against droplets and contact in prevention of nosocomial transmission of severe acute respiratory syndrome (SARS). Lancet. 2003; 361(9368):1519-20.

11. BOSKOSKI I, GALLO C, WALLACE MB, COSTAMAGNA G. COVID-19 pandemic and personal protective equipment shortage: protective efficacy comparing masks and scientific methods for respirator reuse. Gastrointest Endosc. 2020; 92(3):519-23.

12. ASGE COVID-19 FREQUENTLY ASKED QUESTIONS [Internet]. ASGE; Available from: https://www. https://www.asge.org/ docs/default-source/default-document-library/faq_asge_covid19_updated3-31-2020_final.pdf?sfvrsn=dcb28c52_2.

13. CHIU PWY, NG SC, INOUE H, REDDY DN, LING HU E, CHO JY., et al. Practice of endoscopy during COVID-19 pandemic: position statements of the Asian Pacific Society for Digestive Endoscopy (APSDE-COVID statements). Gut. 2020; 69(6):991-6.

14. ZHU J, ZHONG Z, JI P, LI H, LI B, PANG J., et al. Clinicopathological characteristics of 8697 patients with COVID-19 in China: a meta-analysis. Fam Med Community Health. 2020; 8(2): e000406.

15. LACUCCI M, CANNATELLI R, LABARILE N, MAO R, PANACCIONE R, DANESE S., et al. Endoscopy in inflammatory bowel diseases during the COVID-19 pandemic and post-pandemic period. Lancet Gastroenterol Hepatol. 2020; 5(6):598-606.

16. KATARZYNA M. P, JAN K, RISHAD K, SUNIL A, MOHAMMAD B, RASHID N., et al. Impact of COVID-19 on endoscopy trainees: an international survey. Gastrointest Endosc. 2020; 92(4):925-35.

17. DOI A, IWATA K, KURODA H, HASUIKE T, NASU S, KANDA A., et al. Seroprevalence of novel coronavirus disease (COVID-19) in Kobe, Japan. medRxiv. 2020 May 5; 2020.04.26.20079822.

18. TAKITA M, MATSUMOTO T, YAMAMOTO K, YAMASHITA E, HOSODA K, HAMAKI T., et al. Regional Difference in Seroprevalence of SARS-CoV-2 in Tokyo: Results from the community point-of-care antibody testing. medRxiv. 2020 Jun 4; 2020.06.03.20121020.

Received 30 ${ }^{\text {th }}$ September 2020 